\title{
Teacher-Students’ Interactions in Task-Based vs Form-Focused Instruction
}

\author{
Massoud Rahimpour (Corresponding author) \\ The University of Tabriz and The University of Queensland \\ E-mail: rahimpour2003@yahoo.com \\ m.rahimpour@uq.edu.au \\ Massoumeh Magsoudpour \\ English Department, Faculty of Persian Literature and Foreign Languages \\ The University of Tabriz \\ E-mail: magsoudpour2004@yahoo.com
}

Received: January 6, 2011

Accepted: January 24, 2011

doi:10.5430/wje.v1n1p171

\begin{abstract}
Teacher-students' and students-students' interactions are of significant importance in foreign language teaching and learning. It is argued that interactions between teachers and students facilitate language development and lead to better language learning. The present study is an attempt to investigate the effect of two teaching approaches: 1. Task-Based Instruction (TBI) and 2. Form-Focused Instruction (FFI) on the quantity and quality of teacher-students' interactions reflected in the number of occurrences of turn taking, question type, feedback and errors correction. Two groups of intermediate-level learners were selected as the participants of this study. One group was instructed by Form-Focused Instruction (FFI) approach and the other class was instructed by Task-Based Instruction (TBI) approach. Results of the statistical analysis of the collected data revealed that FFI approach led to the occurrence of more teacher-students' interactions than TBI approach. The pedagogical implications are discussed.
\end{abstract}

Keywords: Form-Focused Instruction (FFI), Task-Based Instruction (TBI), Interaction, Turn taking, Question type, Feedback, Error correction

\section{Introduction}

Teacher-students' and students-students' interactions are of significant importance in foreign language development. It is argued that interactions between teachers and students and also interactions among students will facilitate language development and will lead to better language learning. The main purpose of this research is to investigate the impact of two language teaching approaches of Task-Based Instruction (TBI) and Form-Focused Instruction (FFI) on teacherstudents' and students-students' interactions.

\section{Form-Focused Instruction}

According to Ellis (2001) Form-Focused Instruction (FFI) refers to "any planned or incidental instructional activity that is intended to induce language learners to pay attention to linguistic forms". Form-focused instruction "includes both traditional approaches to teaching forms based on structural syllabi and more communicative approaches, where attention to form arises out of activities that are primarily meaning-focused” (Ellis, 2001).

Poole states that focus on form instruction is a type of instruction which:

On one hand holds up the importance of communicative language teaching principles such as authentic communication and student-centeredness, and on the other, maintains the value of the occasional and overt study of problematic L2 grammatical forms (Poole, 2005: 13).

Long's definition of focus on form proposes that learners "attend to language as object during a generally meaningoriented activity," Long states , " learners need to attend to a task if acquisition is to occur, but their orientation can best be to both form and meaning, not to either form or meaning alone” (Long, 1996: 429).

Doughty also points out that: 
The factor that distinguishes focus on form from other pedagogical approaches is the requirement that focus on form involves learner's briefly and perhaps simultaneously attending to form, meaning and use during one cognitive event (Doughty, 2001: 211).

Loewen (2004) believes that when students pay attention briefly to linguistic items which arise spontaneously in meaning-focused activities, the focus on form takes place. This focus on form can be either student-initiated, allowing students to "seek information about linguistic items as the need arises during meaning-focused activities", or teacherinitiated.

\section{Task-Based Instruction}

It was during the 1970s that Brumfit \& Johnson (1979) in the area of language teaching moved away to embrace the communicative approach. The result of this movement, Skehan (2003) argues, was that a range of teaching activities gained prominence which emphasized the need for learners to focus on meaning and to convey information to one another. Widdowson (1978) holds out that at this time the assumption seemed to be that it was not enough in language teaching to focus only in language structure, but that this needed to be accompanied by a concern to develop the capacity to express meanings.

Jeon \& Hahn (2006) believe that the task-based view of language teaching, based on the constructivist theory of learning and communicative language teaching methodology, has evolved in response to some limitations of the traditional PPP approach, represented by the procedure of presentation, practice, and performance (Ellis, 2003; Long \& Crookes, 1991). Thus, it has the substantial implication that language learning is a developmental process promoting communication and social interaction rather than a product acquired by practicing language items, and that learners learn the target language more effectively when they are naturally exposed to meaningful task-based activities.

As Ellis (2004: 3-5) points out, tasks are activities that "call for primarily meaning-focused language use”. Bygate, Skehan and Swain (2001:11) offer a core definition of task, as "an activity which requires learners to use language, with emphasis on meaning, to attain an objective”.

Elsewhere Ellis (2005) argues that task-based approach to language teaching differs from other approaches in that it makes no attempt to stipulate the language forms (and associated meanings) to be taught. Instead "the content is specified holistically in terms of tasks", which can involve listening, speaking, reading or writing or any combination of these skills.

Within the varying interpretations of task-based language teaching related to classroom practice, recent studies exhibit three recurrent features: is com task-based language teaching compatible with a learner-centered educational philosophy (Ellis, 2003b; Nunan, 2005; Richards \& Rodgers, 2001); it consists of particular components such as goal, procedure, specific outcome (Murphy, 2003; Nunan, 2004; Skehan, 1998); it advocates content-oriented meaningful activities rather than linguistic forms (Carless, 2002; Littlewood, 2004).

Jeon \& Hahn (2006) continue that given the fact that language acquisition is influenced by the complex interactions of a number of variables including materials, activities, and evaluative feedback, task-based language teaching has "a dramatic, positive impact on these variables". It implies that task-based language teaching provides learners with natural sources of meaningful material, ideal situations for communicative activity, and supportive feedback allowing for much greater opportunities for language use. Specifically, in an Asian EFL environment where learners are limited in their accessibility to use the target language on a daily basis, it is first of all necessary for language learners to be provided with real opportunities to be exposed to language use in the classroom.

Rahimpour $(2007,2008,2009,2010)$ claims that task-based language teaching creates a favorable condition for language development and consequently facilitates language acquisition. He further argues that the task in task-based language teaching is considered central to the whole instructional design process, from the identification of learner needs to the measurement of student achievement.

\section{Interaction}

Human interaction, Abarca (2004) declares, is a process whereby two or more people engage in reciprocal action. This action may be verbal or non-verbal. Thus for the purpose of teaching a language, teachers mainly focus on the verbal interaction or communicative interaction (Cummins, 1994) without separating the nonverbal interaction that is present at an early phase and which has been called the silent period.

In the educational context, interaction can be regarded as taking place at various levels. Ordinal interaction is unidirectional and consists of the ordering or selection of pre-structural elements. Reciprocal interaction (or tutorial 
interaction) involves the presenting system accepting student input and actively shaping the interaction in response to it (www. Imuaut. Demon.co.uk/trc/edissues/ptgloss.htm).

Elsewhere Abarca (2004) believes that interaction can be described depending on the dominant type of interaction that is taking place in the English classroom. In other words, we have teacher-dominated classroom where the teacher is most of the time talking and student participation is limited; teacher-centered classroom where the teacher is controlling the student participation through some classroom activities and the students have the chance to participate. Finally, the student-centered classroom is the one where the students can participate more actively.

According to Lyster (2006: 270) interaction plays a key role in "deriving L2 development forward because learners rely on semantically contingent speech as a primary source of positive and negative L2 data".

Seedhouse (1999) mentions three characteristics of task-oriented interaction. These characteristics are:

a) that there is a reflexive relationship between the nature of the task and the turn-taking system,

b) that there is a tendency to minimalization and indexicality, and

c) that tasks tend to generate many instances of clarification requests, confirmation checks, comprehension checks, and self-repetitions.

Long (1996) and Gass (2003) have claimed that L2 interaction facilitates learning because, while focusing on communicating, learners can receive feedback and receive opportunities to make use of that feedback by modifying their output.

\subsection{Interaction Process Characteristics in FFI and TBI}

The process characteristics employed in classrooms handled with TBI can be the same as or different from those with FFI. The way teachers and learners interact or communicate with each other, the way teacher responds to them, the way s/he corrects them differs from those employed in FFI. Ellis (2003: 253) argues that there are some processes in TBI and FFI which are quite different from each other. Some of these processes have been classified in Table 1.

$<$ Table 1 about here $>$

Ellis (2003) points out that the set of behaviors arisen in the language classroom depends crucially on the orientation of the participants, whether they regard themselves as 'learners', as is the case in FFI, or 'language users', as is the case in TBI, to the classroom and to their motivation for performing an activity.

Ellis (2003: 252) also believes that it is in task-based teaching that the students are asked to forget where they are and why they are there, and they are also asked to act in a way that they can learn language "indirectly through communicating in it rather than directly through studying it". Ellis (2003) then suggests that the kind of processes mentioned in Table 1 can be best achieved with students interacting among themselves and without the teachers' presence. The above literature review led to the formulation of the following research question and research hypothesis.

\section{The Present Study}

\subsection{Research Questions}

What is the effect of form-based and task-based instructions on the quality and quantity of teacher-students' interaction?

\subsection{Research Hypothesis}

Task-based instruction will lead to more teacher-students' interaction than form-based instruction reflected in the number of interactions.

\section{Method}

\subsection{Participants}

The participants for the study were thirty eight English language learners who were studying English as a foreign language at the intermediate level. Nineteen learners in one class were taught by form-based approach and the other nineteen learners in the other class were taught by task-based approach. A placement test was given to check their homogeneity. The results of the test revealed that participants were roughly at the same level of proficiency.

\subsection{Procedure (Research Instrument)}

As mentioned earlier two groups of students in two classes were chosen as the participants of the study. One class was taught by form-based approach in which the teacher taught the grammar explicitly and the main focus was on enabling the learners to produce correct sentences. The other class was taught by task-based approach in which the grammar was taught implicitly and the main focus was on enabling the learners to communicate easily with focusing on meaning not 
form. Ten sessions of each class were observed and audio-recorded by the researcher with an MP3 player (Media player which records and plays compressed files).

After collecting the data the interactions between teacher and students were transcribed, and reviewed to identify the four interaction process characteristics including turn taking, question type, feedback and errors correction (Ellis, 2003). Then the frequencies of the occurrences of these options were counted.

\section{Results and Statistical Analyses}

Some of the examples driven from the collected data:

Turn-taking was present in every class but it was either done by the teacher or by the learners themselves. In the following example the teacher does the turn-taking;

T: Azizeh ask Hakimeh if she can swim.

L1: Can you swim?

L6: Yes, I can.

Considering question type we can refer to display questions in the interaction between teachers and learners. Display questions are the questions that the questioner knows the answer already, as the following example shows:

\section{T: Request. Ok. What is the verb?}

\section{Ls: Request.}

In form-based feedback, the feedback was given, implicitly or explicitly, to the correct form of the learners' utterances like in the example below:

L5: We are playing sms...

\section{T: We are playing sms or sending sms.}

In explicit error correction, the teacher focuses the learner's attention on the grammatical errors that they may make during their interaction. An example of explicit error correction on form is:

L9: Best friends are, are someone who help our in the wrong...

\section{T: Help us, not our.}

L9: Yes, help us in a problem.

The occurrences of the four interaction process characteristics in task-based and form-focused classes were identified and the frequencies of these were calculated during ten sessions. The total number of frequencies of four interaction process characteristics in form-focused and task-based approaches is presented in Table 2.

$$
<\text { Table } 2 \text { about here }>
$$

The means and the standard deviations of the four interaction process characteristics are illustrated in Table 3.

$$
<\text { Table } 3 \text { about here> }
$$

As Table 3 shows the means of turn taking, question type, feedback, and error correction of form-based class are greater than of task-based class.

These means differences can be more clearly illustrated in the following four figures.

$<$ Figure 1 about here $>$

As Figure 1 illustrates the mean difference of teacher -regulated turn-taking is more than that of task-based class. It means that in form-focused class the teacher does turn-taking.

$<$ Figure 2 about here $>$

The mean difference of display questions is illustrated in Figure 2. What is evident from this figure is the fact that in form-focused class most of the questions asked by the teacher are of the display type.

< Figure 3 about here>

As Figure 3 shows, in form-focused class the type of feedback given by the teacher to the learners are mostly formbased feedback.

\footnotetext{
$<$ Figure 4 about here $>$
} 
And finally in Figure 4 the mean difference of explicit error correction is illustrated in the two classes. It is clearly illustrated that the number of explicit error-correction in form-focused class was more than of the number of explicit error-correction in the task-based class.

For hypothesis testing purpose, Chi-square was employed, as a means of inferential statistical analysis. After finding the total frequencies of the four statistical means in this study, turn-taking, question-type, feedback and error-correction, the expected frequencies for each cell was found in the Table 2. The expected frequency was calculated by the following formula:

\section{Row total $\times$ column total \\ $\mathrm{E}=$ \\ Grand total}

After that the chi-square was calculated by the formula;

$X^{2}=\sum \frac{(O-E)^{2}}{E}$

The chi-square found for this table was;

$X^{2}=18.766$

The degree of freedom (df) found by the formula was:

$\mathrm{df}=($ rows -1$) \times($ columns -1$)$

$\mathrm{df}=3$

Referring to the chi-square, $X^{2}=7.815$ with $3 \mathrm{df}$ at the 5 per cent significance level, the $X^{2}$ obtained (18.766) is more than this table value. Therefore our hypothesis that the task-based instruction leads to more teacher-students' interaction was accepted.

\section{Discussion}

On the basis of the findings of the descriptive and referential statistics, it was found that in task-based instruction, the interaction of teacher and learners is more than of form-based instruction. This is evident by comparing the interaction process characteristics in the two approaches.

It was also found that in form-based class the teacher and learners paid more attention to the structure of what they produced. For example, they tried to correct and complete sentences and they rarely used phrases. On the other hand in task-based class the main focus was on enabling the students to communicate without worrying so much about the correctness of what they produced. Therefore, it can be concluded that these two teaching approaches were different in the use of the interaction process characteristics.

On the basis of the analysis of the collected data, it was also proved that task-based instruction led to more teacherstudents' interaction than form-based instruction which was reflected in the number of the interaction process characteristics. This can be better understood by counting the frequencies of the process characteristics occurring in the two classes. As the results revealed, in form-based class the frequencies of interaction process characteristics were more than of task-based class. Ultimately the overall results led to the acceptance of our hypothesis .

\section{Conclusion and Implications}

To draw a conclusion, we should claim that the two types of task-based and form-focused teaching approaches have different impact on the quantity and quality of interactions which occur between teacher and learners which will ultimately lead to better foreign language development. Therefore, on the basis of the main objectives of the course and students' needs, foreign language instructors can employ relevant teaching approach to meet their learners' needs.

The findings of this study are of particular relevance to task-based language learning and teaching and to the areas of ESL, ESP, TESOL, TOFEL and in particular for teaching speaking. The findings also have theoretical and practical considerations for syllabus designers and material developers. 


\section{References}

Abarca, F.A. (2004). Interaction in the English classroom: an exploratory study. Actualidades Investigativas on Educacion, 4 (1), 1-24.

Brumfit, C. \& Johnson, K. (1979). The communicative approach to language teaching. Oxford: Oxford University Press. Bygate, M., Skehan, P. \& Swain, M. (2001), (Eds.). Researching pedagogic tasks: second language learning, teaching, and testing. London: Longman.

Carless, D. (2002). Implementing task-based learning with young learners. ELT Journal, 56 (4), 389-396.

Doughty, C. (2001). Cognitive underpinnings of focus on form. In P. Robinson (Ed.). Cognition and second language acquisition, (pp. 206-257). Cambridge: Cambridge University Press.

Ellis, R. (2003). Designing a task-based syllabus. RELC Journal, 34, 664-681.

Ellis, R. (2004). The definition and measurement of explicit knowledge. Language learning, 54, $227-275$.

Ellis, R. (2005). Instructed second language acquisition: a literature review. New Zealand: Ministry of Education.

Gass, S.M. (2003). Input and interaction. In C.J. Doughty and M.H. Long, Malden (Eds.). Handbook of second language acquisition, (pp. 224-255). MA: Blackwell.

Jeon, I. J., \& Hahn, J. W. (2006). Exploring EFL teacher's perceptions of task-based language teaching: a case study of Korean secondary school classroom practice. Linguistics Journal, 8 (1). March 06 home.htm.

Ki, W.W. (1997). ICT Applications in task-based language teaching (Chapter 6). Adobe Reader-[06ch_06E.PDF].

Littlewood, W. (2004). The task-based approach: some questions and suggestions. ELT, 58 (4), $319-326$. doi:10.1093/elt/58.4.319, http:// dx.doi.org/10.1093/elt/58.4.319

Loewen, S. (2004). The occurrence and characteristics of student-initiated focus on form. Proceedings of the Independent Learning Conference 2003. Retrieved from www.independentlearning.org/:1a03/ila03_Loewen \%20.

Long, M. (1996). The role of linguistic environment in second language acquisition. In W.C. Ritchie \& T.K. Bhatia (Eds.). Handbook of second language acquisition, (pp. 414-468). New York: Academic Press. doi:10.1016/B978012589042-7/50015-3, http:// dx.doi.org/10.1016/B978-012589042-7/50015-3

Lyster, R., \& Mori, H. (2006). Interactional feedback and instructional counterbalance. SSLA, 28, $269-300$.

Morley, J. (2001). Aural comprehension instruction: principles and practices. In Celce-Murcia, M. (Ed.). Teaching English as a Second or Foreign Language ( $3^{\text {rd }}$ ed.), (pp. 69-85). United States: Heinle \& Heinle.

Murphy, J. (2003). Task-based learning: the interaction between tasks and learners. ELT Journal, 57(4), 352-360. doi:10.1093/elt/57.4.352, http:// dx.doi.org/10.1093/elt/57.4.352

Nunan, D. (2004). Task-Based language teaching. Cambridge: Cambridge University Press. doi:10.1017/CBO9780511667336, http:// dx.doi.org/10.1017/CBO9780511667336

Nunan, D. (2005). Important tasks of English education: Asia-wide and beyond. Asian EFL Journal Vol. 7 , Issue 3.

Poole, A. (2005). Focus on form instruction: foundations, applications, and criticisms. The Reading Matrix, 5 (1), $47-56$.

Rahimpour, M. (2010). Current trends on syllabus design in foreign language instruction. Procedia- Social and Behavioral Sciences.Vol.2, Issue 2, pp.1660-1664.

Rahimpour, M. (2009). Impact of task condition on L2 learners' oral performance. Journal of Faculty of Letters \& Humanities, No.208, 13-23.

Rahimpour, M. (2008). Implementation of task-based approaches to language teaching. Foreign Languages Research (Pajohesh-e-Zabanhay-e- Khareji), Special Issue in English, Tehran University, No, 41, 45.61.

Rahimpour, M. (2007). Task complexity and variation in L2 learners' oral discourse. The University of Queensland Working papers in Linguistics, Vol. 1 Australia.

Richards, J., \& Rodgers, T. (2001). Approaches and methods in language teaching. Cambridge: Cambridge University Press. doi:10.1017/CBO9780511667305, http:// dx.doi.org/10.1017/CBO9780511667305

Seedhouse, P. (1999). Task-based interaction. ELT Journal, 53(3), 149-156. doi:10.1093/elt/53.3.149, http://dx.doi.org/10.1093/elt/53.3.149

Skehan, P. (1998). A cognitive approach to language learning. Oxford: Oxford University Press. 
Table 1: Process options in TBI and FFI Taken from Ellis (2003:253)

\begin{tabular}{|l|l|}
\hline Form-focused pedagogy & Task-based pedagogy \\
\hline Use of display questions & Use of referential questions \\
\hline Form-focused feedback & Content-focused feedback \\
\hline Teacher-regulated turn-taking & Self-selected turn-taking \\
\hline Exposed or explicit error-correction & Embedded /implicit error-correction \\
\hline
\end{tabular}

Table 2: Total frequencies of the processes in form-based and task-based classes

\begin{tabular}{|l|c|c|c|c|}
\hline Classes & $\begin{array}{c}\text { Turn-taking } \\
\text { Total }\end{array}$ & $\begin{array}{c}\text { Question type } \\
\text { Total }\end{array}$ & $\begin{array}{c}\text { Feedback } \\
\text { Total }\end{array}$ & $\begin{array}{c}\text { Error correction } \\
\text { Total }\end{array}$ \\
\hline Form-based class & 163 & 131 & 131 & 86 \\
\hline Task-based class & 67 & 87 & 66 & 17 \\
\hline
\end{tabular}

Table 3: Means ( $\bar{X}$ ) and Standard Deviations (SD) of the interaction process characteristics in Form-based and Taskbased classes

\begin{tabular}{|l|c|c|c|c|c|c|c|c|}
\hline \multirow{2}{*}{ Classes } & \multicolumn{2}{|c|}{ Turn taking } & \multicolumn{2}{c|}{ Question type } & \multicolumn{2}{c|}{ Feedback } & \multicolumn{2}{c|}{ Error correction } \\
\cline { 2 - 9 } & $\bar{X}$ & $S D$ & $\bar{X}$ & $S D$ & $\bar{X}$ & $S D$ & $\bar{X}$ & $S D$ \\
\hline $\begin{array}{l}\text { Form- } \\
\text { based }\end{array}$ & 8.578 & 3.233 & 6.894 & 2.712 & 6.894 & 3.176 & 4.526 & 3.151 \\
\hline $\begin{array}{l}\text { Task- } \\
\text { based }\end{array}$ & 3.526 & 2.583 & 4.578 & 2.389 & 3.473 & 2.347 & 0.894 & 0.911 \\
\hline
\end{tabular}

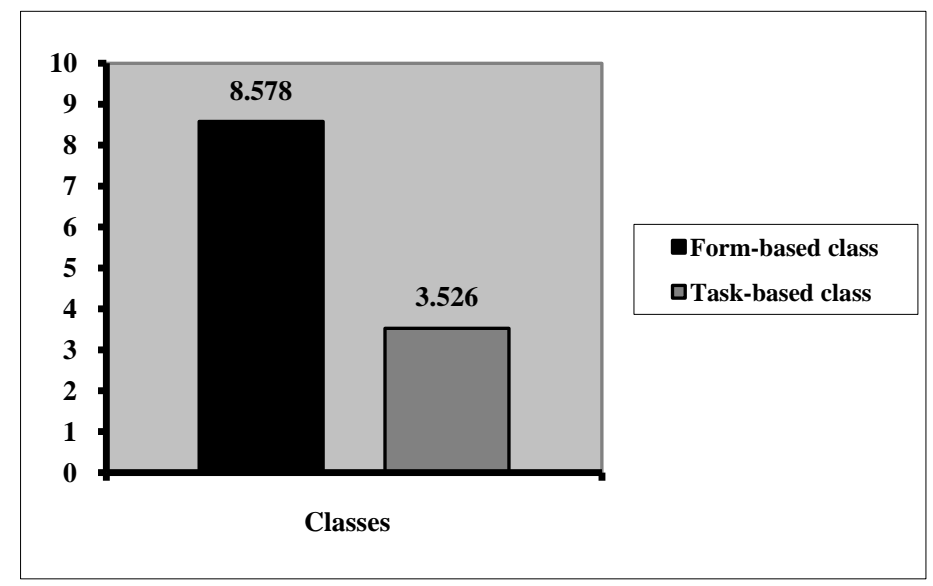

Figure 1: Mean difference of turn-taking in Task-based and Form-based classes 


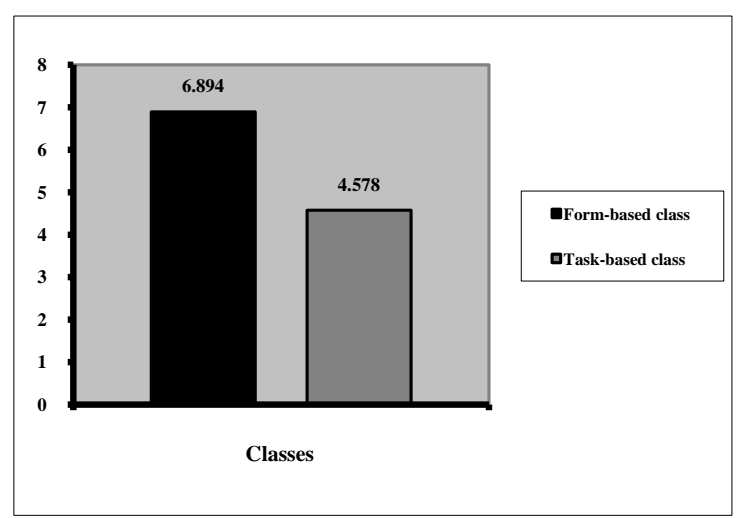

Figure 2: Mean difference of question type in task-based and form-based classes

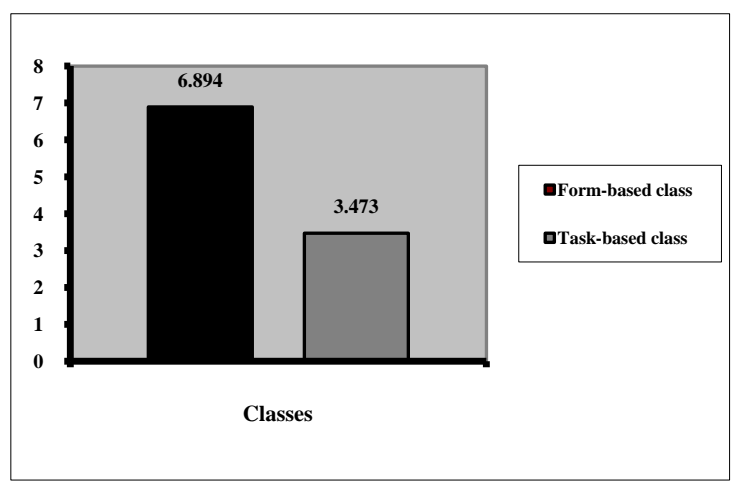

Figure 3: Mean difference of feedback in task-based and form-based classes

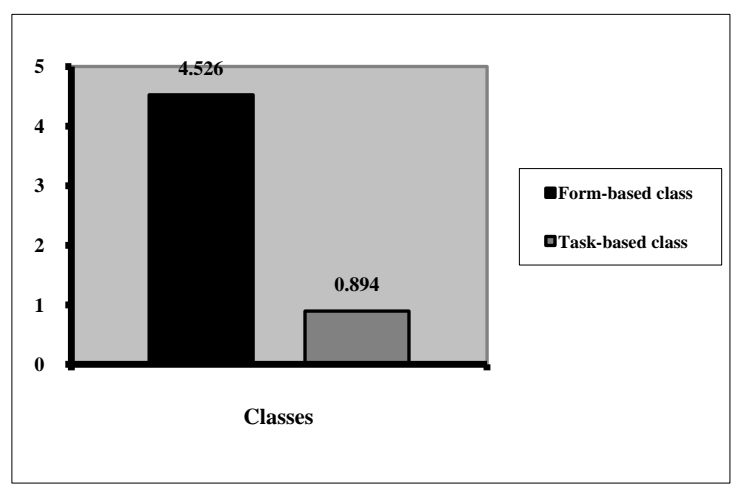

Figure 4: Mean difference of Error Correction in Task-based and Form-based Classes 